\title{
Social capital and social exclusion in England and Wales (1972-1999)
}

\begin{abstract}
Recent research on social capital has explored trends in membership in voluntary organizations. However, there is currently little robust evidence on such trends in the UK since the 1970s, nor is there any analysis of whether participation bridges social divisions or accentuates them. This paper explores trends in participation in England and Wales since 1972 using data from the Social Mobility Inquiry of 1972 and the British Household Panel Survey of 1992 and 1999. We are concerned with social exclusion mechanisms in social capital generation in Britain over the three decades. Using binomial and multinomial models to 'unpack' the effects of socio-cultural factors on civic participation and on different types of associational membership, we test the thesis of across-the-board decline in social capital by Putnam (2000) and that of rising levels of middle-class social capital versus consistent low levels of working-class social capital by Hall (1999). The results show significant socio-cultural-gender differences, a relative stability of middle-class participation, and a rapid decline in the working-class access to social capital. We challenge the established accounts of both theses.
\end{abstract}

KEYWORDS: Associational involvement; social network; mobility trajectory; social capital; social class; social exclusion

\section{INTRODUCTION}

Over the past decade a number of leading social scientists have argued that social capital is a crucial force that generates a wide range of positive social outcomes, from economic prosperity, through democratic political forms, to individual well-being (see Putnam 1993; 2000). However, the concept of social capital remains an infuriating one. It gestures both towards involvement in formal voluntary associations and to a range of informal social networks, making it difficult to define with any precision. The mechanisms that are seen as producing trust and co-operation remain a matter for debate (Anheier and Kendall 2002). Most importantly, a number of social 
scientists have framed a critical concept of social capital that argues that it produces modes of exclusion and social inequality (Bourdieu 1986; Portes 1998; Lin 2001). The aim of this paper is to provide support for this critical approach to social capital. Using authoritative data from Social Mobility Inquiry (SMI) of 1972 and the British Household Panel Survey (BHPS) of 1992 and 1999, we show how membership of voluntary associations is related to forms of social exclusion, with evidence that there is increasing class polarization in associational membership in British society.

Currently there is only a limited amount of research on social capital in the UK (Hall 1999; Warde et al. 2001; Li et al. 2002; Li, Savage and Pickles 2003) as compared to the USA (Putnam 2000; Paxton 1999). This paper seeks to break new ground by developing a critical account of social capital. We show how associational membership is related to social class and gender divisions, and how social change since the 1970s is affecting the distribution of social capital. In so doing, we are able to adjudicate between the view of Putnam (2000) and that of Hall (1999) on the general decline versus general increase in social capital.

The next part of the paper highlights theoretical debates regarding social capital and shows how there is currently unrealized potential in examining the social differentiation of membership, and how this differentiation is changing over time. The third part of the paper gives a brief description of the data and the methods we use. Section four turns to the heart of our analysis, looking at the distribution and character of social capital. We measure social capital in terms both of participation in civic organizations and of types of associational memberships. In the latter respect, we develop a theoretically-grounded approach to membership types to stand for different channels of social capital generation. We validate this measure against the social character of the participants in terms both of the propensity of people in different classes to participate in civic organizations and of the members' social class self-identification. Section 4.1 focuses on class and gender differences in social capital between 1992 and 1999, and Section 4.2 examines trends in the class differences in social capital for men between 1972 and 1999. Section 5 wraps up our findings and relates them to debates on social capital.

\section{FRAMING A CRITICAL CONCEPT OF SOCIAL CAPITAL}

Interest in the concept of social capital can be related to two connected processes: firstly a convergence of interest in the mechanisms producing social co-operation from different social science disciplines, and secondly Putnam's elaboration of a template for showing how the concept can be researched empirically. These twin processes have allowed theoretical and empirical work to bear on each other in an unusually harmonious way and allow remarkable potential for the concept of social capital to reconfigure existing debates and develop new lines of research throughout much of the 
social sciences. However, this same situation also allows the proliferation of theoretical position-taking as differing intellectual camps stake their jurisdiction over the concept of social capital. This situation is exacerbated because of the hybrid theoretical origins of the concept itself, since it originates in Coleman's (1988) rational choice theory, Bourdieu's (1986) reflexive sociology of practice, and developments in neo-classical economics (see Fine 2001). In the hands of Putnam (1993, 2000), the concept gestures towards the diffuse world of 'norms, networks and trust', a means of emphasizing the importance of what has been termed 'civil society' - social relationships grounded neither in the institutions of the state nor in the complex of economic relationships of capitalist societies (for earlier discussions see Urry 1981; Cohen and Arato 1992). However, given the inevitable elasticity of civil society, it is always likely that writers in different traditions will seek to 'rein in' social capital to their own (often disciplinary) purposes. Indeed, this is already apparent in recent syntheses and discussions (generally Portes 1998; Jackman and Miller 1998; Foley and Edwards 1997). Some writers seek to oppose the concept as marking the improper colonization of the social by disciplines such as economics (Fine 2001). Others have sought to domesticate the concept into their own disciplines. Within sociology, for instance, Walters (2002) incorporates it into neo-Foucauldian concerns with governmentality, whilst Urry (2002) extends it into his new sociology of mobility. Still others have used the concept to replay older debates such as that between state-centred and society-centred approaches to social and political change (Levi 1996; Skocpol 1996). In all these cases we see the potential for interdisciplinary debate being foreclosed as the established disciplines seek to chart out their stakes and appropriate the concept to their own disciplinary purposes (see generally Abbott 2001).

It is because of the resulting fraught nature of theoretical debate on social capital that Putnam's elaboration of a model for empirical research takes on particular importance. Putnam has in fact provided two different models. In Making Democracy Work (1993), Putnam uses a careful historical analysis to argue that the voluntary associations found in Northern Italy help explain its greater democratic vitality compared to Southern Italy. Here he elaborates a neo-Tocquevillian approach to the positive social virtues of voluntary associations. Putnam defines social capital as 'features of social organization such as networks, norms, and social trust that facilitate coordination and cooperation for mutual benefit' (1996: 67), and gives analytical priority to voluntary associations as crucibles in which networks, norms and trust are linked in a virtuous circle. In his subsequent work, Bowling Alone (2000), Putnam extends his interests to the USA, and uses a more diffuse definition of social capital that includes informal networks to argue that a significant fall in social capital poses worrying problems for the future of democratic cultures. Here he uses survey data on voluntary associational memberships and informal sociability activities, and skillfully interprets the wide-ranging patterns to claim that there is a general trend towards disengagement in American life. 
Whilst Putnam's empirical research has provided a model, there are serious conceptual problems that he skirts over. The most important of these is his insufficient attention to the possibility that social capital can divide as well as unify. Although he distinguishes between bridging and bonding social capital, and allows that the latter kind may generate forms of exclusion, he does not use this distinction in his empirical account. ${ }^{1}$ Bourdieu's (1984) perspective is particularly important here as a corrective (see Portes 1998 and Fine 2001). Bourdieu refers to social capital as 'the aggregate of the actual or potential resources which are linked to possession of a durable network of more or less institutionalized relations of mutual acquaintance or recognition' (1986: 248). Unlike Coleman (1988) and other theorists, Bourdieu emphasizes that social capital is not a means of encouraging generalized trust, but a means for particular social groups to retain their exclusiveness by forming tight bonds with others similar to themselves. Certainly Hall (1999) in his study of social capital in the UK explicitly draws attention to class differences in associational membership, and in addition there is a large body of literature that testifies to the extent that civic participation is related to class and gender divisions (Parry et al. 1992).

One current weakness in the critical perspective is that it remains empirically under-developed. It is difficult to assess empirically whether social capital tends to divide or unify because we lack robust ways of empirically adjudicating on this issue. It is certainly true that social network analysis allows one way of differentiating between bridging and bonding social capital through its ability to measure the density of ties (see e.g. Scott 1991). Thus, if your friends A, B, and C all know each other, this indicates that this group is well 'bonded' in Putnam's terms. However, in order to assess whether ties are densely connected or not, it is necessary to collect detailed network information on a wide number of friends and contacts, and this is rarely done within representative national surveys. The British Household Panel Survey, for instance, asks respondents to list their three closest friends, but because it does not ask whether these friends know each other, it is not possible to determine how well bonded, and densely tied they are.

Given these difficulties, this paper seeks a different way of assessing whether social capital is exclusive or not, by considering whether forms of social capital are specific to certain classes or able to reach across class boundaries. By exploring the social composition and the social determinants of associational membership it is possible to assess whether different kinds of association act as bonding social capital - socially exclusive to particular social groups - or bridging social capital, able to recruit a diverse array of people. In so doing, we are able to empirically adjudicate between bridging and bonding social capital using national survey data. Furthermore, we can use the same data sets to present a rigorous account of trends over time that marks an advance beyond Hall's descriptive cross-tabulations. By examining the impact of class position, educational qualifications, mobility trajectories and friendship networks on different kinds of 
associational membership, we seek to show the processes associated with the social exclusion in social capital generation.

\section{DATA AND METHODS}

We use two data sets for this research: the Social Mobility Inquiry (SMI) of 1972 and the British Household Panel Survey (BHPS) ${ }^{2}$ of 1992 and 1999. Both data sets have information on associational involvement and a whole range of socio-cultural variables, which enables us to explore which factors affected social capital generation in British society over the three decades. The SMI has a sample of 10,309 men in England and Wales in 1972 and is the largest such survey carried out during the 1970s (see Goldthorpe et al. 1987). The BHPS began in 1990 as the premier British panel study, and surveys around 5,000 households and 10,000 individuals annually. Both data sets contain information on, among other things, the respondent's mobility trajectories, educational qualifications, friendship ties and associational involvement. Although different clusters of questions are asked in the BHPS from year to year, the questions on associational involvement asked in Waves 2 and 9 (1992 and 1999) are similar to those in the SMI of 1972. The use of these surveys allows us to standardize procedures in testing trends in social capital generation in British society over the past three decades.

We measure the respondent's mobility trajectories at three points in time: their current class, their class at the entry to the labour market after leaving full-time education (first-job class), and their parental class. The respondent's current class is based on his or her current job (or last main job if the information on current occupation is not available). Parental class refers to father's job when the respondent was aged around 14 . Where father's class is not available, mother's class is used, which is the practice in the SMI and is here applied to the BHPS. First-job class in the BHPS is obtained from work-histories at Wave 3 and the subsequent updates. We adopt a version of class schema widely used in British research (Goldthorpe et al. 1987), to wit, a three-way classification that distinguishes a service class of professionals, administrators and managers; an intermediate class of routine-non-manual employees, small owners, manual supervisors and lower-grade technicians; and a working class of skilled, semi-skilled and unskilled workers including agricultural labourers.

With regard to the respondent's friend's class, we are, unfortunately, only able to use a two-way classification between the service and the non-service class. This is because the SOC (standard occupational classification) codes for the 'best friend' available in the BHPS do not permit detailed differentiation among the non-service-class. It is also to be noted that, in the SMI, the identified person is referred to as the 'most frequent spare-time associate' rather than 'friend'. To be compatible with the terminology in the BHPS and with the general practice in previous research using the SMI 
(Heath 1981; Mitchell and Critchley 1985; Li 1997), he/she is called 'friend' in the present paper. ${ }^{3}$ For the BHPS, Wave 2 has data on associational involvement and all the socio-cultural variables including friend's class. Wave 9 has information on the respondent's associational involvement and socio-cultural variables, but it has been necessary to draw the friendship data from Wave 8 .

With regard to the respondent's educational qualifications, we use a three-way variable: degree or professional qualifications, A/O Levels, and vocational or no qualifications. Variables for associational involvement have been standardized to ensure comparability between the data sets. ${ }^{4}$ Finally, as the SMI only has information on men aged 20 to 64 and resident in England and Wales at the time of interview, we restrict the analysis on the BHPS to respondents within the same age and geographic ranges.

Our analysis uses both descriptive statistics and logit modelling as appropriate for the tasks at hand. As the two waves from the BHPS are used for cross-sectional comparisons, rather than longitudinally, we use the crosssectional weights in the data. The analyses are conducted via Stata 7 with analytical weights in descriptive analysis and probability weights in the modelling procedures. With regard to models, these were estimated using pseudo-likelihood, with standard errors, confidence intervals and p-values all based on a robust estimator of the parameter covariance matrices as described in the complex survey literature (Binder 1983), econometrics (White 1982) and theoretical statistics (Huber 1967).

\section{ANALYSING SOCIAL DIFFERENCES IN SOCIAL CAPITAL IN ENGLAND AND WALES (1972-1999)}

\subsection{Class and Gender Differences in Social Capital Generation (1992-1999)}

Many existing studies take membership in civic organizations as an indicator of the stock of social capital in society. However, it is not clear that associations are socially homogeneous, and indeed Hall (1999) argues that in the UK, 'the working class draws its organizational affiliations disproportionately from trade unions and working-men's clubs' (1999: 456). Hall's argument can be supported by the evidence (Table I) that people in different social classes tend to be in one rather than another civic organization. As shown under the headings of 'service-: working- class ratios', service-class men and women in both data sets were less likely (with the exception of women in trade unions) to participate in trade unions and working-men's clubs, but were much more likely to be in the other civic organizations than their counterparts in the working class. There was not only a clear class difference in the propensity to join different civic organizations, but the members in different organizations also exhibited a clear difference in their world outlook as indexed through self-identified working-class status. ${ }^{5}$ Thus, those who joined trade unions and working-men's clubs were noticeably more (around 60 per cent) likely than 
TABLE I: Service-class to working-class membership ratios in civic organizations and percentages of respondents in each civic organization who identify themselves as working class

\begin{tabular}{|c|c|c|c|c|c|c|c|c|}
\hline & \multicolumn{4}{|c|}{1992} & \multicolumn{4}{|c|}{1999} \\
\hline & \multicolumn{2}{|c|}{$\begin{array}{l}\text { Service: working } \\
\text { class ratios }\end{array}$} & \multicolumn{2}{|c|}{$\begin{array}{l}\text { Self-identified } \\
\text { working class } \\
(\%)\end{array}$} & \multicolumn{2}{|c|}{$\begin{array}{l}\text { Service: working } \\
\text { class ratios }\end{array}$} & \multicolumn{2}{|c|}{$\begin{array}{l}\text { Self-identified } \\
\text { working class } \\
\qquad(\%)\end{array}$} \\
\hline & Men & Women & Men & Women & Men & Women & Men & Women \\
\hline \multicolumn{9}{|l|}{ Civic organizations } \\
\hline Trade unions & 0.81 & 2.36 & 54.5 & 48.1 & 0.79 & 2.45 & 59.3 & 50.9 \\
\hline $\begin{array}{l}\text { Working men's or social } \\
\text { clubs }\end{array}$ & 0.53 & 0.58 & 60.8 & 60.1 & 0.58 & 0.67 & 59.8 & 54.9 \\
\hline Sports/hobby clubs & 1.86 & 2.86 & 43.4 & 38.7 & 1.67 & 3.24 & 45.5 & 41.7 \\
\hline Professional associations & - & - & - & - & 28.92 & 51.76 & 25.6 & 30.8 \\
\hline $\begin{array}{l}\text { Church or religious } \\
\text { groups }\end{array}$ & 2.84 & 2.37 & 32.3 & 38.2 & 2.96 & 2.57 & 30.4 & 37.8 \\
\hline $\begin{array}{l}\text { Tenants'/residents' } \\
\text { groups }\end{array}$ & 3.89 & 2.82 & 38.8 & 41.7 & 2.39 & 2.42 & 42.9 & 45.9 \\
\hline $\begin{array}{l}\text { Parent-teacher } \\
\text { associations }\end{array}$ & 5.22 & 3.54 & 28.9 & 35.9 & 5.36 & 4.91 & 29.3 & 32.4 \\
\hline Political party & 4.94 & 5.31 & 37.8 & 38.1 & 3.18 & 3.95 & 46.4 & 35.6 \\
\hline $\begin{array}{l}\text { Voluntary services } \\
\text { groups }\end{array}$ & 2.89 & 2.56 & 38.2 & 37.5 & 2.22 & 3.14 & 34.2 & 38.8 \\
\hline Environmental group & 6.69 & 5.01 & 37.0 & 24.1 & 4.28 & 6.00 & 36.8 & 38.8 \\
\hline $\begin{array}{l}\text { Other community/civic } \\
\text { groups }\end{array}$ & 5.50 & 2.48 & 36.9 & 29.5 & 2.39 & 1.33 & 27.3 & 36.8 \\
\hline $\begin{array}{l}\text { Women's institutes/ } \\
\text { groups }\end{array}$ & - & 3.71 & - & 30.9 & - & 6.85 & - & 38.1 \\
\hline $\begin{array}{l}\text { Scouts/guides } \\
\text { organizations }\end{array}$ & - & - & - & - & 1.34 & 3.47 & 41.6 & $50.1^{\mathrm{a}}$ \\
\hline Pensioners' group & - & - & - & - & 1.64 & $0.70^{\mathrm{a}}$ & $58.3^{\mathrm{a}}$ & $45.6^{\mathrm{a}}$ \\
\hline Other & 3.08 & 4.96 & 41.7 & 33.3 & 1.89 & 2.35 & 40.2 & 30.4 \\
\hline $\begin{array}{l}\text { All (in any civic } \\
\text { organization) }\end{array}$ & 1.25 & 1.83 & 48.3 & 43.3 & 1.18 & 1.88 & 50.4 & 46.3 \\
\hline $\mathrm{N}$ & 2,444 & 2,715 & 2,021 & 2,312 & 2,020 & 2,327 & 1,659 & 1,918 \\
\hline
\end{tabular}

Source: The British Household Panel Survey (BHPS) of 1992 and 1999.

Note:

$\mathrm{a}=$ Cell sizes less than 30 .

people in the other organizations (around 40 per cent) to say that they belonged to the working class. This pattern again holds for men and women alike and in both of the data sets.

The evidence in Table I suggests two broad types of association: trade unions and/or working-men's clubs as a 'working-class-dominated' or 'Labour' type of engagement, and all other organizations as a 'service-classdominated' or 'Civic' type of engagement. We therefore made such a differentiation as substantiated by the patterns. As some people joined 'Labour' or 'Civic' types alone, others joined both types and still others 
joined neither of them (i.e. in none of the listed civic organizations), we created a four-way, mutually-exclusive, variable for membership types: 'Both', 'Civic', 'Labour' and 'Neither'. Further analysis again shows that this classification of civic memberships has convincing criterion validity. Logistic regression models show that, even controlling for the respondent's objective class, educational qualifications, friend's class and mobility trajectories, those in the 'Labour' type were consistently more, just as those in the 'Civic' type were consistently less, likely to regard themselves as being working class (see data in Appendix Table I).

The evidence thus gives us considerable confidence that the membership types provide very different kinds of social capital. The 'Labour' type tends to be associated with working-class occupations and is conducive to working-class identities, and the 'Civic' type is stronger amongst the service class and is associated with middle-class identities. In the following, we shall explore the socio-cultural differences in the dimensions and implications of civic engagement using this variable.

Having cleared the ground, we proceed to show the association between socio-cultural attributes (class and education) and membership types for men and women in 1992 and 1999. The data are presented in Table II. In Panel 1 of the table on the relationship between class and membership types, we also show, under the heading 'All', the overall proportions of each of the four membership categories. We find that women were much more likely than men to be disengaged from any kind of civic engagement. Forty-five per cent of women were found in the 'Neither' type in 1992 and 1999, but the figures for men were much lower, at 32 and 36 per cent respectively. Whilst there was little change in women's membership profiles between the two time points, the increase in the rates of men's non-participation was, upon closer inspection, caused by the drop in the 'Labour' type.

The class differences associated with different membership types manifest themselves very clearly as shown in Panel 2 of the table. Around 40 per cent of working-class men and 60 per cent of working-class women were in the 'Neither' group, which are roughly 1.5 and 2 times that of service-class men and women. Working-class men were around 18 percentage points more likely to be in the 'Labour' type than the serviceclass men but the latter were much more likely to be in 'Civic' and 'Both' types (by around 25 and 7 points). In fact, for men and women alike and at both time points, around 40 per cent of the service class were in the 'Civic' type. With the exception of men in the 'Neither' category in 1999, the intermediate class stood in between the service class and the working class in each of the membership categories.

The pattern of association between education and membership types is similar to that between class and membership types, which is not surprising given the close association between education and class (Marshall, Swift and Roberts 1997). Thus, for both men and women and at both time points, we find that the poorly educated, namely those with only vocational or no 
TABLE II: Membership types by class and education for men and women (1992-1999) (percentage by column)

\begin{tabular}{|c|c|c|c|c|c|c|c|c|c|c|c|c|c|c|c|c|}
\hline \multirow[b]{3}{*}{ Panel 1: by class } & \multicolumn{8}{|l|}{1992} & \multicolumn{8}{|l|}{1999} \\
\hline & \multicolumn{4}{|l|}{ Men } & \multicolumn{4}{|l|}{ Women } & \multicolumn{4}{|l|}{ Men } & \multicolumn{4}{|l|}{ Women } \\
\hline & SV & INT & WC & All & SV & INT & WC & All & SV & INT & WC & All & SV & INT & WC & All \\
\hline Both & 23.5 & 18.5 & 16.8 & 19.7 & 18.6 & 7.8 & 4.3 & 9.9 & 23.2 & 15.4 & 16.1 & 18.7 & 20.3 & 7.2 & 5.7 & 11.0 \\
\hline Civic & 40.7 & 28.2 & 15.3 & 28.5 & 40.5 & 34.6 & 20.0 & 32.5 & 41.1 & 26.8 & 17.6 & 29.6 & 40.3 & 35.1 & 19.7 & 33.3 \\
\hline Labour & 12.4 & 17.6 & 29.9 & 19.7 & 11.7 & 10.8 & 15.3 & 12.2 & 7.5 & 14.3 & 26.3 & 15.4 & 10.4 & 9.3 & 14.6 & 10.9 \\
\hline Neither & 23.5 & 35.8 & 38.1 & 32.1 & 29.4 & 46.8 & 60.4 & 45.4 & 28.2 & 43.5 & 40.0 & 36.3 & 29.0 & 48.4 & 60.0 & 44.9 \\
\hline All & 100.0 & 100.0 & 100.0 & 100.0 & 100.0 & 100.0 & 100.0 & 100.0 & 100.0 & 100.0 & 100.0 & 100.0 & 100.0 & 100.0 & 100.0 & 100.0 \\
\hline $\mathrm{N}$ & 1,070 & 949 & 874 & 2,993 & 921 & 1,492 & 856 & 3,269 & 1,108 & 818 & 877 & 2,803 & 983 & 1,426 & 700 & 3,109 \\
\hline Panel 2: by education & $\mathrm{D} / \mathrm{P}$ & $\mathrm{A} / \mathrm{O}$ & $\mathrm{V} / \mathrm{N}$ & & $\mathrm{D} / \mathrm{P}$ & $\mathrm{A} / \mathrm{O}$ & $\mathrm{V} / \mathrm{N}$ & & $\mathrm{D} / \mathrm{P}$ & $\mathrm{A} / \mathrm{O}$ & $\mathrm{V} / \mathrm{N}$ & & $\mathrm{D} / \mathrm{P}$ & $\mathrm{A} / \mathrm{O}$ & $\mathrm{V} / \mathrm{N}$ & \\
\hline Both & 24.6 & 21.2 & 13.1 & & 19.7 & 7.3 & 5.1 & & 22.4 & 16.5 & 14.1 & & 17.8 & 7.7 & 4.8 & \\
\hline Civic & 39.9 & 28.3 & 17.7 & & 41.7 & 36.2 & 23.2 & & 37.2 & 28.3 & 16.9 & & 42.3 & 30.7 & 23.1 & \\
\hline Labour & 12.9 & 18.4 & 27.1 & & 11.1 & 12.6 & 12.0 & & 10.1 & 16.5 & 24.4 & & 9.7 & 9.8 & 13.1 & \\
\hline Neither & 22.6 & 32.2 & 42.1 & & 27.6 & 44.0 & 59.8 & & 30.3 & 39.4 & 44.6 & & 29.8 & 51.8 & 59.0 & \\
\hline All & 100.0 & 100.0 & 100.0 & & 100.0 & 100.0 & 100.0 & & 100.0 & 100.0 & 100.0 & & 100.0 & 100.0 & 100.0 & \\
\hline $\mathrm{N}$ & 1,043 & 943 & 1,047 & & 877 & 1,104 & 1,400 & & 1,317 & 806 & 676 & & 1,243 & 997 & 931 & \\
\hline
\end{tabular}

Source: The British Household Panel Survey (BHPS) of 1992 and 1999.

Notes:

1 For class, SV: the service class; INT: the intermediate class; WC: the working class.

2 For education, D/P: degree or professional qualifications; A/O: A/O Levels; V/N: vocational or no qualifications.

3 For membership types:

Both: participation in both 'Civic' and 'Labour' types of associations,

Civic: participation in any of the listed organizations except trade unions or working-men's clubs,

Labour: participation in trade unions or working-men's clubs only,

Neither: participation in neither 'Civic' nor 'Labour' types of associations. 
qualifications, and particularly poorly-educated women, were most likely to be disengaged from any kind of civic organizations. On the other hand, people with the highest educational qualifications (degree or professional qualifications) were most likely to be in the 'Civic' type - they were twice as likely to be in such organizations as the poorly qualified. Moreover, the best qualified were also more likely to be in the 'Both' type than those with A/ O Levels or vocational/no qualifications.

The overall impression from Table II suggests important differences between socio-cultural groups over membership types. The less advantaged groups, be they by class or education, were more likely to be totally disengaged from civic participation, and hence to be deprived of access to formal channels of social capital generation. Those in advantaged socio-cultural positions were particularly likely to be engaged in 'Civic' and 'Both' rather than the 'Labour' types.

Having looked at the patterns of association between socio-cultural conditions and membership types, we shall proceed to a more formal test, which we do in two ways. First, we shall take any form of civic participation as a generalized source of social capital. We shall then take membership types as different channels of social capital generation. In both tests, we shall focus on socio-cultural and gender differences that, as we have discussed earlier, may be expected to affect people's access to social capital. These factors include class, education, mobility trajectories ${ }^{6}$ and friend's class.

Table III shows the effects of socio-cultural-demographic attributes on civic participation. We use logistic regression models to see who are likely to be in civic organizations (members $=1$, non-members $=0$ ). Model 1 is main effects alone. Model 2 includes interaction effects between gender and class, and between gender and education, which will allow us to examine class and education effects associated with a particular gender group. Model 3 also includes interaction effects between socio-cultural attributes and period. However, as shown in the test statistic at the bottom of the table, there are no additional significant effects for Model 3, suggesting that the relative effects of class and education did not change between 1992 and 1999. We therefore only discuss findings from Models 1 and 2.

Model 1 shows that, after controlling for the other socio-cultural factors, women were less likely than men to participate in civic associations; that civic engagement was lower in 1999 than in 1992; that people in the service class, with higher or intermediate qualifications, coming from service-class families or having service-class friends were significantly more likely to be in civic associations; and that those who had experienced upward mobility in their work-lives were significantly less likely to be in civic organizations than is the norm for their destination class.

While the patterns in Model 1 reinforced the findings of important class and gender differences as earlier observed, they do not reveal whether men and women in the same class or educational positions would be similarly 
TABLE III: Logistic regression models on civic participation for men and women (1992-99)

\begin{tabular}{|c|c|c|c|}
\hline & Model 1 & Model 2 & Model 3 \\
\hline \multicolumn{4}{|l|}{ (a) Main effects } \\
\hline \multicolumn{4}{|l|}{ Class } \\
\hline Service class & $.946^{* * *}$ & $.659^{* * *}$ & $.638^{* * * *}$ \\
\hline Intermediate class & .096 & $-.289^{*}$ & $-.294^{*}$ \\
\hline \multicolumn{4}{|l|}{ Working class (base) } \\
\hline \multicolumn{4}{|l|}{ Educational qualifications } \\
\hline Degree/professional qualifications & $.689^{* * *}$ & $.547^{* * *}$ & $.578^{* * *}$ \\
\hline A/O Levels & $.301^{* * * *}$ & .214 & $.289^{*}$ \\
\hline \multicolumn{4}{|l|}{ Vocational/none (base) } \\
\hline \multicolumn{4}{|l|}{ Intergenerational mobility } \\
\hline Upward mobility & -.179 & -.176 & -.174 \\
\hline Downward mobility & $.224^{*}$ & $.229^{*}$ & $.228^{*}$ \\
\hline \multicolumn{4}{|l|}{ Work-life mobility } \\
\hline Upward mobility & $-.396^{* *}$ & $-.389^{* *}$ & $-.389^{* *}$ \\
\hline Downward mobility & .194 & .173 & .174 \\
\hline \multicolumn{4}{|l|}{ Friendship networks } \\
\hline Having service-class friends & $.239^{* * *}$ & $.244^{* * * *}$ & $.244^{* * *}$ \\
\hline \multicolumn{4}{|l|}{ Not having service-class friends (base) } \\
\hline \multicolumn{4}{|l|}{ Gender } \\
\hline Female & $-.378^{* * *}$ & $-.983^{* * *}$ & $-.992^{* * *}$ \\
\hline \multicolumn{4}{|l|}{ Male (base) } \\
\hline \multicolumn{4}{|l|}{ Period } \\
\hline 1999 & $-.129^{*}$ & $-.138^{*}$ & -.069 \\
\hline \multicolumn{4}{|l|}{1992 (base) } \\
\hline \multicolumn{4}{|l|}{ (b) Interaction effects } \\
\hline Women in service-class positions & & $.593^{* * *}$ & $.596^{* * *}$ \\
\hline Women in intermediate-class positions & & $.729^{* * *}$ & $.729^{* * *}$ \\
\hline Women with degree/professional quals & & .256 & .254 \\
\hline Women with A/O Levels & & .127 & .129 \\
\hline Service class in 1999 & & & .041 \\
\hline Intermediate class in 1999 & & & .008 \\
\hline Degree/professional qualifications in 1999 & & & -.076 \\
\hline A/O Levels in 1999 & & & -.184 \\
\hline Constant & .125 & $.437^{* * *}$ & $.409^{* * *}$ \\
\hline $\mathrm{N}$ & 5,836 & 5,836 & 5,836 \\
\hline \multirow{2}{*}{$\begin{array}{r}\text { Model comparison } \chi^{2} \\
\text { p-value }\end{array}$} & - & $31.250^{\mathrm{a}}$ & $1.580^{\mathrm{b}}$ \\
\hline & - & $<.001$ & .813 \\
\hline
\end{tabular}

Notes:

$1{ }^{*} \mathrm{p}<0.05,{ }^{* *} \mathrm{p}<0.01$, and ${ }^{* * *} \mathrm{p}<0.001$ (the same below in the models).

2 Because of the amount of data used, standard errors are not presented (the same below in the models).

3 Adjusted Wald tests are used to test the additional blocks of model terms.

4 arefers to terms in Model 2 that are additional to those in Model 1. ${ }^{\text {b }}$ refers to terms in Model 3 that are additional to those in Model 2.

engaged in civic organizations. This we show in Model 2 by combining main and interaction effects. The additional terms in Model 2 make a significant improvement in fit. Although there was no significant interaction between 
gender and education, gender differences in civic participation did vary according to class positions. Nevertheless, tests of specific contrasts showed, with all other variables in the model held constant, that men in each class and at each level of education were significantly more likely than women in the same class/educational position to be in civic organizations, and that women in higher classes and with higher qualifications were significantly more likely than women in lower class or educational positions to be in civic organizations. ${ }^{7}$

The findings in Table III also suggest that, in terms of the relative importance of the factors as seen from the magnitude of the coefficients, it is class that has the greatest effect, followed by education. These are highly important findings in view of the current debate on social capital and provide us with a much more precise picture of the processes of social capital generation than can be gleaned from descriptive analysis alone. Yet, important as they are, the findings do not show the socio-cultural differences in the types of associational memberships that, as noted earlier, may serve as indicating different channels of social capital generation for different social groups. It is to this end that we return our attention, to the socio-cultural differences for men and women in the 1990s.

As there are four categories in the membership types, we use multinomial logit models with 'Neither' as the omitted category (Table IV). Model 1 of the table shows that, when only the main effects are considered and after controlling for changes in the included socio-cultural attributes, memberships in 'Labour' type of organizations experienced a significant decline from 1992 to 1999 whereas the decline in the other two types was smaller and non-significant. With similar socio-cultural attributes, women were significantly less likely than men to find themselves in 'Labour' and 'Both', but not in 'Civic', type. With regard to socio-cultural factors, it is the service class, those with higher qualifications and with service-class friends who were more likely to be in 'Both' and 'Civic' types of organizations. The mobility trajectory effects, whether inter- or intra- generational, were more clearly shown in the 'Civic' type, with those downwardly mobile being more, and those upwardly mobile being less, likely than expected for their destination class to have memberships in this type when all other factors in the model are simultaneously considered. Those upwardly mobile in their work lives showed a lower level of participation in the 'Both' type than expected for their destination class. These patterns suggest that 'Both' and 'Civic' types of membership were 'home' to the more advantaged groups. With regard to 'Labour' type, the most interesting finding relates to the greater propensity to join this type of organization by those with highest educational qualifications and with intergenerational upward mobility trajectories.

The test statistics at the bottom of the table show that, whilst there are significant interaction effects between gender and socio-cultural factors (Model 2 over Model 1), there are no additional interaction effects between 
TABLE IV: Multinomial logit models for membership types of civic organizations for men and women (1992-1999)

\begin{tabular}{|c|c|c|c|}
\hline & Model 1 & Model 2 & Model 3 \\
\hline \multicolumn{4}{|l|}{ Both } \\
\hline \multicolumn{4}{|l|}{ Class } \\
\hline Service class & $.993^{* * *}$ & $.555^{* *}$ & $.576^{*}$ \\
\hline Intermediate class & -.013 & $-.369^{*}$ & -.250 \\
\hline \multicolumn{4}{|l|}{ Working class (base) } \\
\hline \multicolumn{4}{|l|}{ Educational qualifications } \\
\hline Degree/professional qualifications & $.870^{* * * *}$ & $.742^{* * *}$ & $.762^{* * * *}$ \\
\hline A/O Levels & $.333^{* *}$ & $.473^{* *}$ & $.530^{* *}$ \\
\hline \multicolumn{4}{|l|}{ Vocational/none (base) } \\
\hline \multicolumn{4}{|l|}{ Intergenerational mobility } \\
\hline Upward mobility & .059 & .068 & .069 \\
\hline Downward mobility & .118 & .140 & .139 \\
\hline \multicolumn{4}{|l|}{ Work-life mobility } \\
\hline Upward mobility & $-.553^{* * *}$ & $-.538^{* * *}$ & $-.537^{* * *}$ \\
\hline Downward mobility & -.254 & -.289 & -.291 \\
\hline \multicolumn{4}{|l|}{ Friendship networks } \\
\hline Having service-class friends & $.296^{* *}$ & $.298^{* *}$ & $.297^{\text {** }}$ \\
\hline Not having service-class friends (base) & & & \\
\hline \multicolumn{4}{|l|}{ Gender } \\
\hline Female & $-.845^{\text {**** }}$ & $-1.838^{* * *}$ & $-1.839^{* * * *}$ \\
\hline \multicolumn{4}{|l|}{ Male (base) } \\
\hline \multicolumn{4}{|l|}{ Period } \\
\hline 1999 & -.079 & -.080 & -.088 \\
\hline \multicolumn{4}{|l|}{1992 (base) } \\
\hline \multicolumn{4}{|l|}{ Interaction effects } \\
\hline Women in service-class positions & & $1.339^{* * * *}$ & $1.331^{* * * *}$ \\
\hline Women in intermediate-class positions & & $1.114^{* * * *}$ & $1.118^{* * * *}$ \\
\hline Women with degree/professional quals & & .247 & .259 \\
\hline Women with A/O Levels & & $-.449^{*}$ & $-.497^{*}$ \\
\hline Service class in 1999 & & & -.043 \\
\hline Intermediate class in 1999 & & & .269 \\
\hline Degree/professional qualifications in 1999 & & & -.053 \\
\hline A/O Levels in 1999 & & & -.143 \\
\hline Constant & $-1.190^{* * *}$ & $-.874^{* * * *}$ & $.949^{* * * *}$ \\
\hline \multicolumn{4}{|l|}{ Civic } \\
\hline \multicolumn{4}{|l|}{ Class } \\
\hline Service class & $1.449^{* * *}$ & $1.444^{* * *}$ & $1.426^{* * * *}$ \\
\hline Intermediate class & .493 & .293 & .265 \\
\hline \multicolumn{4}{|l|}{ Working class (base) } \\
\hline \multicolumn{4}{|l|}{ Educational qualifications } \\
\hline Degree/professional qualifications & $.804^{* * * *}$ & $.798^{* * *}$ & $.811^{\text {**** }}$ \\
\hline A/O Levels & $.424^{* * *}$ & $.317^{* *}$ & $.403^{* *}$ \\
\hline Vocational/none (base) & & & \\
\hline
\end{tabular}


TABLE IV: Continued

\begin{tabular}{|c|c|c|c|}
\hline & Model 1 & Model 2 & Model 3 \\
\hline \multicolumn{4}{|l|}{ Intergenerational mobility } \\
\hline Upward mobility & $-.420^{* * *}$ & $-.424^{* * * *}$ & $-.421^{* * * *}$ \\
\hline Downward mobility & $.443^{* * *}$ & $.435^{* * *}$ & $.435^{* * *}$ \\
\hline \multicolumn{4}{|l|}{ Work-life mobility } \\
\hline Upward mobility & $-.322^{*}$ & $-.318^{*}$ & $-.319^{*}$ \\
\hline Downward mobility & $.382^{*}$ & $.389^{*}$ & $.392^{*}$ \\
\hline \multicolumn{4}{|l|}{ Friendship networks } \\
\hline $\begin{array}{l}\text { Having service-class friends } \\
\text { Not having service-class friends (base) }\end{array}$ & $.332^{* * * *}$ & $.333^{* * *}$ & $.334^{* * *}$ \\
\hline \multicolumn{4}{|l|}{ Gender } \\
\hline $\begin{array}{l}\text { Female } \\
\text { Male (base) }\end{array}$ & -.026 & -.104 & -.104 \\
\hline \multicolumn{4}{|l|}{ Period } \\
\hline $\begin{array}{l}1999 \\
1992 \text { (base) }\end{array}$ & -.122 & -.128 & -.088 \\
\hline \multicolumn{4}{|l|}{ Interaction effects } \\
\hline Women in service-class positions & & -.013 & -.006 \\
\hline Women in intermediate-class positions & & .289 & .289 \\
\hline Women with degree/professional quals & & .011 & .006 \\
\hline Women with $\mathrm{A} / \mathrm{O}$ Levels & & .154 & .157 \\
\hline Service class in 1999 & & & .043 \\
\hline Intermediate class in 1999 & & & .061 \\
\hline Degree/professional qualifications in 1999 & & & -.044 \\
\hline A/O Levels in 1999 & & & -.219 \\
\hline Constant & $-1.204^{* * *}$ & $-1.148^{* * *}$ & $-1.164^{* * *}$ \\
\hline \multicolumn{4}{|l|}{ Labour } \\
\hline \multicolumn{4}{|l|}{ Class } \\
\hline Service class & -.399 & $-.751^{* *}$ & $-.739^{* *}$ \\
\hline $\begin{array}{l}\text { Intermediate class } \\
\text { Working class (base) }\end{array}$ & $-.393^{* * * *}$ & $-.720^{* * *}$ & $-.749^{* * *}$ \\
\hline \multicolumn{4}{|l|}{ Educational qualifications } \\
\hline Degree/professional qualifications & $.280^{*}$ & .059 & .139 \\
\hline A/O Levels & .084 & -.041 & .014 \\
\hline \multicolumn{4}{|l|}{ Vocational/none (base) } \\
\hline \multicolumn{4}{|l|}{ Intergenerational mobility } \\
\hline Upward mobility & $.417^{*}$ & $.417^{*}$ & $.418^{*}$ \\
\hline Downward mobility & -.276 & -.271 & -.271 \\
\hline \multicolumn{4}{|l|}{ Work-life mobility } \\
\hline Upward mobility & -.226 & -.212 & -.208 \\
\hline Downward mobility & -.035 & -.078 & -.079 \\
\hline \multicolumn{4}{|l|}{ Friendship networks } \\
\hline $\begin{array}{l}\text { Having service-class friends } \\
\text { Not having service-class friends (base) }\end{array}$ & -.063 & -.055 & -.055 \\
\hline
\end{tabular}


TABLE IV: Continued

\begin{tabular}{lccc}
\hline & Model 1 & Model 2 & Model 3 \\
\hline Gender & & & \\
Female & $-.646^{* * *}$ & $-1.350^{* * *}$ & $-1.348^{* * * *}$ \\
Male (base) & & & \\
Period & & & \\
1999 & $-.189^{*}$ & $-.199^{*}$ & -.111 \\
1992 (base) & & & \\
Interaction effects & & & \\
Women in service-class positions & & $.802^{* *}$ & $.805^{* * *}$ \\
Women in intermediate-class positions & & $.682^{* *}$ & $.679^{* *}$ \\
Women with degree/professional quals & & $.481^{*}$ & .476 \\
Women with A/O Levels & & .248 & .249 \\
Service class in 1999 & & .054 \\
Intermediate class in 1999 & & .070 \\
Degree/professional qualifications in 1999 & & & -.175 \\
A/O Levels in 1999 & & & -.132 \\
Constant & $-.409^{* * *}$ & -.088 & -.123 \\
N & 5,836 & 5,836 & 5,836 \\
Model comparison $\chi^{2}$ & - & $82.300^{\mathrm{a}}$ & $5.680^{\mathrm{b}}$ \\
$\quad$ p-value & - & $<.001$ & .932 \\
\hline
\end{tabular}

Note:

1 Adjusted Wald tests are used to test the additional blocks of model terms.

$2{ }^{a}$ refers to terms in Model 2 that are additional to those in Model $1 .{ }^{\text {b }}$ refers to terms in Model that are additional to those in Model 2.

3 For asterisks please see Note 1, Table III.

period and socio-cultural conditions (Model 3 over Model 2). Thus class and educational effects operated in 1999 just as they did in 1992.

To further examine the class and gender differences, we conducted further tests based on the main and the interaction effects in Model 2. The results show that, with all other factors in the model controlled for, men in each class and at each level of educational qualifications were significantly more likely than women of the same socio-cultural attributes to be in 'Both' and 'Labour', but not in 'Civic', type. ${ }^{8}$ A reason for this may be that men are more likely to be in employment than women and that even when in work, women tend to be in the service sector where trade unions are less developed. The findings here in turn suggest support for the postulation above that the 'Civic' type of membership is more diffused, less related to the work-place and more likely to engender a generalized source of social capital. As for the class differences among women, further analysis shows a clear class gradient in 'Both' and 'Civic', but not in the 'Labour' type, with service-class women significantly, at the 0.001 levels, more likely than women in intermediate and working-class positions to be in the two types of organizations while holding constant all other factors in the model. Highly educated women were, other things being equal, significantly more likely to be in each of the three membership types than women in the 
intermediate or bottom level of education. This forms an interesting contrast with men with regard to 'Labour' type in particular. ${ }^{9}$

In sum, the analysis above shows significant differences between gender groups and between class and educational positions in both the generalized form of civic engagement and different types of associational involvement in Britain in the 1990s. The patterns offer a valuable insight into the mechanisms of social capital generation that, we believe, is the best evidence available on gender and class differences. Yet, it is also the case that, in order to offer a more comprehensive evaluation of the theses on social capital such as those proffered by Putnam (2000) and Hall (1999), we need to extend our horizon. The next subsection will explore trends in social capital for men in Britain from the early 1970s to the late 1990s.

\subsection{Trends of Social Capital Among Men (1972-1999)}

There are two perspectives on trends in social capital. The first may be called the thesis of general or across-the-board decline of social capital developed by Putnam (1995, 1996, 2000) with special respect to US society. Putnam argues that 'despite rapid increases in education that have given more of us than ever before the skills, the resources and the interests that once fostered civic engagement ... Americans have been dropping out in droves, not merely from political life, but from organized community life more generally' (Putnam 2000: 64). Although whether America has experienced a declining social capital is much debated (see, for instance, Paxton 1999), it would be of interest to see whether the thesis would apply to the British society. If it does, we would expect a decline in social capital and that decline would occur for all socio-cultural groups. The second thesis is more specifically geared to British society. Hall (1999) claims that there is no decline in social capital in Britain due primarily to educational reform, the growth of the middle class, and government policy. He further states that the growing middle class has increased its levels of social capital and that the contracting working class has maintained similar, or similarly low, levels of social capital. The end result of this, according to Hall, is that the overall level of social capital has been sustained, but the class differences between the middle and the working classes have been deepened and the working class has been increasingly marginalized (1999: Table 1 and p. 439).

In the following subsection, we test the theses on the trends of social capital in British society on the basis of the SMI (1972) and the BHPS (1999) for men. We shall first look at the general patterns, and then model the association between socio-cultural factors and social capital indicators.

Table $\mathrm{V}$ shows the data on class and educational association with membership types for men in 1972. Comparing the patterns in this table with the corresponding data for men in 1999 in Table II, we find, firstly, that tremendous changes had taken place in the social structure in Britain over the three decades, with the service class much expanded (from 24.7 per 
cent in 1972 to 39.5 in 1999) and the working class much contracted (from 45.2 to 33.3 per cent) (see also Li 2002). The proportion of men with degrees or professional qualifications was also much higher in 1999 (47.1 per cent) than in 1972 (10.3 per cent). One might expect this to lead to an increase in social capital, yet the overall level of civic engagement has, however, experienced a marked decline, from 23 per cent of men in 1972 reporting no membership in any formal civic organizations to 36 per cent in 1999. A closer look suggests, however, that there is a growth of 5 percentage points in the 'Civic' type, and that the greatest decline is associated with membership in trade unions and working-men's clubs ('Labour' and associated 'Both'). (See also Gallie, Penn and Rose 1996 for more discussion of trade unions in Britain.)

The trends of class differences in civic participation manifest themselves in a way unpredicted by hypotheses by Putnam and Hall. For instance, the service class witnessed a drop of 11 percentage points and the working class that of 16 points in terms of civic participation between 1972 and 1999 . These figures raise doubts both on the thesis of the 'across-the-board' decline by Putnam (2000) and on the thesis of increasing levels of middleclass participation by Hall (1999). The association between education and civic participation also witnessed considerable changes. In 1972, over half (55 per cent) of the men with degree/professional qualifications were in 'Civic' type of organizations but the rate was reduced to 37 per cent in 1999. In 1972, only a quarter of the men with vocational or no formal qualifications were disengaged but the proportion was increased to 45 per cent in 1999.

To further test the theses by Putnam and Hall as discussed earlier, we proceed to the statistical modelling of the data. Table VI shows the results

TABLE V: Membership types by class and education for men in 1972 (percentage by column)

\begin{tabular}{lcccc}
\hline Panel 1: by class & Service class & Intermediate class & Working class & All \\
Both & 26.8 & 23.1 & 26.9 & 25.8 \\
Civic & 45.4 & 27.9 & 11.2 & 24.7 \\
Labour & 11.4 & 23.2 & 38.2 & 27.1 \\
Neither & 16.5 & 25.7 & 23.6 & 22.5 \\
& & & & \\
All & 100.0 & 100.0 & 100.0 & 100.0 \\
N & 2,840 & 3,025 & 4,545 & 10,050 \\
& & & & \\
Panel 2: by education & Degree/professional & A/O Levels & Vocational/none & \\
Both & 28.8 & 26.6 & 24.9 & \\
Civic & 54.5 & 39.1 & 18.5 & \\
Labour & 5.5 & 16.1 & 31.7 & \\
Neither & 11.3 & 18.2 & 24.9 & \\
All & & & & \\
N & 100.0 & 100.0 & 100.0 & \\
\hline
\end{tabular}

Source: The Social Mobility Inquiry (SMI) of 1972. 
TABLE VI: Logistic regression models on civic participation for men (1972-99)

\begin{tabular}{|c|c|c|c|c|}
\hline & $\begin{array}{c}\text { Model } 1 \\
1972\end{array}$ & $\begin{array}{c}\text { Model } 2 \\
1999\end{array}$ & $\begin{array}{l}\text { Model } 3 \\
\text { 1972-99 }\end{array}$ & $\begin{array}{l}\text { Model } 4 \\
\text { 1972-99 }\end{array}$ \\
\hline \multicolumn{5}{|l|}{ Main effects } \\
\hline \multicolumn{5}{|l|}{ Class } \\
\hline Service class & -.331 & $.639^{*}$ & .113 & -.237 \\
\hline Intermediate class & $-.253^{* *}$ & $-.420^{*}$ & $-.229^{* * * *}$ & $-.240^{* *}$ \\
\hline Working class (base) & & & & \\
\hline \multicolumn{5}{|l|}{ Educational qualifications } \\
\hline Degree/professional qualifications & $.948^{* * *}$ & $.511^{* * *}$ & $.666^{* * *}$ & $.935^{* * *}$ \\
\hline A/O Levels & .203 & .118 & .159 & .174 \\
\hline \multicolumn{5}{|l|}{ Vocational/none (base) } \\
\hline \multicolumn{5}{|l|}{ Intergenerational mobility } \\
\hline Upward mobility & .321 & -.364 & .014 & .315 \\
\hline Downward mobility & -.054 & -.037 & -.062 & -.052 \\
\hline \multicolumn{5}{|l|}{ Work-life mobility } \\
\hline Upward mobility & -.048 & -.208 & -.136 & -.112 \\
\hline Downward mobility & .146 & .099 & .096 & .124 \\
\hline \multicolumn{5}{|l|}{ Friendship networks } \\
\hline $\begin{array}{l}\text { Having service-class friends } \\
\text { Not having service-class friends (base) }\end{array}$ & .181 & .076 & .107 & .099 \\
\hline \multicolumn{5}{|l|}{ Period } \\
\hline $\begin{array}{l}1999 \\
1972 \text { (base) }\end{array}$ & & & $-1.135^{* * *}$ & $-1.074^{* * *}$ \\
\hline \multicolumn{5}{|l|}{ Interaction effects } \\
\hline Service-class in 1999 & & & & $.711^{*}$ \\
\hline Intermediate-class in 1999 & & & & -.207 \\
\hline $\begin{array}{l}\text { Degree/professional qualifications in } \\
1999\end{array}$ & & & & -.400 \\
\hline $\begin{array}{l}\text { Intergenerational upward mobility in } \\
1999\end{array}$ & & & & $-.666^{*}$ \\
\hline Constant & $1.510^{* * * *}$ & $.492^{* * * *}$ & $1.522^{* * *}$ & $1.515^{* * *}$ \\
\hline $\mathrm{N}$ & 5,024 & 1,189 & 6,213 & 6,123 \\
\hline Model comparison $\chi^{2}$ & - & - & - & $11.130^{\mathrm{a}}$ \\
\hline p-value & - & - & - & .025 \\
\hline
\end{tabular}

Note:

1 Adjusted Wald tests are used to test the additional blocks of model terms.

2 a refers to terms in Model 4 that are additional to those in Model 3.

3 For asterisks please see Note 1, Table III.

of logistic regression models predicting membership in civic organizations. Models 1 and 2 show the patterns in 1972 and 1999 separately. These give us a clear indication of where the greatest changes have occurred. In Model 3 , we combine the data and include the period effect through the use of a dummy variable $(1999=1,1972=0)$. In Model 4 , we further include interaction effects between period and class, higher educational qualifications and intergenerational upward mobility. ${ }^{10}$ The terms included in the interactions are not only substantively meaningful in view of the changes of 
TABLE VII: Multinomial logit models for membership types of civic organizations for men in 1972 and 1999

\begin{tabular}{|c|c|c|c|c|}
\hline & Model 1 & Model 2 & Model 3 & Model 4 \\
\hline & 1972 & 1999 & 1972-99 & 1972-99 \\
\hline \multicolumn{5}{|l|}{ Both } \\
\hline \multicolumn{5}{|l|}{ Class } \\
\hline Service class & $-.742^{* *}$ & .420 & -.292 & $-.670^{* *}$ \\
\hline Intermediate class & $-.383^{* * *}$ & $-.623^{* *}$ & $-.432^{* * *}$ & $-.458^{* * *}$ \\
\hline Working class (base) & & & & \\
\hline \multicolumn{5}{|l|}{ Education } \\
\hline Degree/professional qualifications & $.975^{* * *}$ & $.612^{* *}$ & $.744^{* * * *}$ & $.925^{* * *}$ \\
\hline A/O Levels & .252 & .173 & .202 & $.229^{*}$ \\
\hline \multicolumn{5}{|l|}{ Vocational/none (base) } \\
\hline \multicolumn{5}{|l|}{ Intergenerational mobility } \\
\hline Upward mobility & $.678^{* * * *}$ & .263 & $.429^{* *}$ & $.694^{* * *}$ \\
\hline Downward mobility & -.262 & .186 & -.195 & -.242 \\
\hline \multicolumn{5}{|l|}{ Work-life mobility } \\
\hline Upward mobility & -.061 & -.449 & -.200 & -.197 \\
\hline Downward mobility & .095 & -.172 & .001 & .025 \\
\hline \multicolumn{5}{|l|}{ Friendship network } \\
\hline Having service-class friends & $.240^{* *}$ & -.028 & .161 & $.246^{*}$ \\
\hline \multicolumn{5}{|l|}{ Not having service-class friends (base) } \\
\hline \multicolumn{5}{|l|}{ Period } \\
\hline 1999 & & & $-1.127^{* * * *}$ & $-1.375^{\text {**** }}$ \\
\hline \multicolumn{5}{|l|}{1972 (base) } \\
\hline \multicolumn{5}{|l|}{ Interaction effects } \\
\hline Service-class men in 1999 & & & & $1.037^{* *}$ \\
\hline Degree/professional qualifications in 1999 & & & & -.265 \\
\hline Intergenerationally upward mobile in 1999 & & & & -.561 \\
\hline $\begin{array}{l}\text { Intergenerationally downward mobile in } \\
1999\end{array}$ & & & & .363 \\
\hline Having service-class friends in 1999 & & & & -.280 \\
\hline Constant & $.567^{* * *}$ & $.651^{* *}$ & $.580^{* * *}$ & $.592^{* * *}$ \\
\hline \multicolumn{5}{|l|}{ Civic } \\
\hline \multicolumn{5}{|l|}{ Class } \\
\hline Service class & $.953^{* * * *}$ & $1.515^{* * *}$ & $1.280^{* * * *}$ & $.940^{* * * *}$ \\
\hline Intermediate class & $.530^{* * * *}$ & .173 & $.472^{* * * *}$ & $.453^{* * *}$ \\
\hline Working class (base) & & & & \\
\hline \multicolumn{5}{|l|}{ Education } \\
\hline Degree/professional & $1.155^{* * *}$ & $.678^{* *}$ & $.931^{* * *}$ & $1.137^{* * * *}$ \\
\hline A/O Levels & $.289^{* *}$ & .163 & $.279^{*}$ & $.268^{*}$ \\
\hline \multicolumn{5}{|l|}{ Vocational/none (base) } \\
\hline \multicolumn{5}{|l|}{ Intergenerational mobility } \\
\hline Upward mobility & .021 & $-.756 * *$ & -.292 & .026 \\
\hline Downward mobility & .334 & -.228 & .297 & .355 \\
\hline
\end{tabular}


TABLE VII: Continued

\begin{tabular}{|c|c|c|c|c|}
\hline & $\begin{array}{c}\text { Model } 1 \\
1972 \\
\end{array}$ & $\begin{array}{c}\text { Model } 2 \\
1999 \\
\end{array}$ & $\begin{array}{l}\text { Model } 3 \\
\text { 1972-99 }\end{array}$ & $\begin{array}{l}\text { Model } 4 \\
1972-99 \\
\end{array}$ \\
\hline \multicolumn{5}{|l|}{ Work-life mobility } \\
\hline Upward mobility & -.067 & -.098 & -.108 & -.102 \\
\hline Downward mobility & .405 & .191 & .301 & .335 \\
\hline \multicolumn{5}{|l|}{ Friendship network } \\
\hline $\begin{array}{l}\text { Having service-class friends } \\
\text { Not having service-class friends (base) }\end{array}$ & $.409^{* * *}$ & .042 & $.303^{* * *}$ & $.420^{*}$ \\
\hline \multicolumn{5}{|l|}{ Period } \\
\hline $\begin{array}{l}1999 \\
1972 \text { (base) }\end{array}$ & & & $-1.106^{* * *}$ & $-.847^{* * *}$ \\
\hline \multicolumn{5}{|l|}{ Interaction effects } \\
\hline Service-class men in 1999 & & & & $.752^{*}$ \\
\hline $\begin{array}{l}\text { Degree/professional qualifications in } \\
1999\end{array}$ & & & & -.414 \\
\hline $\begin{array}{l}\text { Intergenerationally upward mobile in } \\
1999\end{array}$ & & & & $-.787^{* * *}$ \\
\hline $\begin{array}{l}\text { Intergenerationally downward mobile } \\
\text { in } 1999\end{array}$ & & & & -.189 \\
\hline Having service-class friends in 1999 & & & & $-.409^{*}$ \\
\hline Constant & $-.471^{* * * *}$ & $-1.068^{* * * *}$ & $-.405^{* * *}$ & $-.430^{* * *}$ \\
\hline \multicolumn{5}{|l|}{ Labour } \\
\hline \multicolumn{5}{|l|}{ Class } \\
\hline Service class & $-1.622^{* * * *}$ & $-1.201^{*}$ & $-1.420^{* * *}$ & $-1.663^{* * * *}$ \\
\hline $\begin{array}{l}\text { Intermediate class } \\
\text { Working class (base) }\end{array}$ & $-.579^{* * * *}$ & $-.806^{*}$ & $-.629^{* * * *}$ & $-.634^{* * * *}$ \\
\hline \multicolumn{5}{|l|}{ Education } \\
\hline Degree/professional & -.097 & .161 & .017 & -.093 \\
\hline A/O Levels & .029 & .089 & .016 & .035 \\
\hline Vocational/none (base) & & & & \\
\hline \multicolumn{5}{|l|}{ Intergenerational mobility } \\
\hline Upward mobility & $.746^{* *}$ & .173 & $.504^{*}$ & $.746^{* *}$ \\
\hline Downward mobility & -.210 & $-.912^{*}$ & -.318 & -.203 \\
\hline \multicolumn{5}{|l|}{ Work-life mobility } \\
\hline Upward mobility & .181 & .330 & .232 & .197 \\
\hline Downward mobility & -.112 & .279 & -.077 & -.044 \\
\hline \multicolumn{5}{|l|}{ Friendship network } \\
\hline $\begin{array}{l}\text { Having service-class friends } \\
\text { Not having service-class friends (base) }\end{array}$ & -.206 & -.391 & $-.277^{* *}$ & $-.201^{* *}$ \\
\hline \multicolumn{5}{|l|}{ Period } \\
\hline 1999 & & & $-1.012^{* * * *}$ & $-1.035^{* * *}$ \\
\hline
\end{tabular}


TABLE VII: Continued

\begin{tabular}{|c|c|c|c|c|}
\hline & Model 1 & Model 2 & $\begin{array}{l}\text { Model } 3 \\
1972-99\end{array}$ & $\begin{array}{l}\text { Model } 4 \\
1972-99\end{array}$ \\
\hline \multicolumn{5}{|l|}{ Interaction effects } \\
\hline Service-class men in 1999 & & & & .645 \\
\hline $\begin{array}{l}\text { Degree/professional qualifications } \\
\text { in } 1999\end{array}$ & & & & .225 \\
\hline $\begin{array}{l}\text { Intergenerationally upward mobile } \\
\text { in } 1999\end{array}$ & & & & -.562 \\
\hline $\begin{array}{l}\text { Intergenerationally downward } \\
\text { mobile in } 1999\end{array}$ & & & & -.674 \\
\hline Having service-class friends in 1999 & & & & -.192 \\
\hline Constant & $.786^{* * * *}$ & -.178 & $.810^{* * * *}$ & $.807^{* * * *}$ \\
\hline $\mathrm{N}$ & 5,024 & 1,189 & 6,213 & 6,213 \\
\hline Model comparison $\chi^{2}$ & - & - & - & $20.670^{\mathrm{a}}$ \\
\hline $\mathrm{p}$-value & - & - & - & .042 \\
\hline
\end{tabular}

Notes:

1 Adjusted Wald tests are used to test the additional blocks of model terms.

2 a refers to terms in Model 4 that are additional to those in Model 3.

3 For asterisks please see Note 1, Table III.

patterns in Models 1 and 2, but also yield a significant improvement in the fit of the model as seen at the bottom of the table.

We have seen, in Table V, that, even in 1972, the working class was more likely to be disengaged (23.6 per cent) than the service class (16.5 per cent). Yet, somewhat surprisingly as shown in Model 1 of Table VI for 1972, when all other factors in the model are taken into account, the class effects were generally non-significant and the intermediate class actually showed a negative effect as compared with the working class; only higher education had the significant positive effect on civic participation, which also proved to have the greatest relative importance in terms of the magnitude of coefficients. When we move to the patterns in Model 2 for 1999, we find that the effect of the service class changed from a non-significant -.331 in 1972 to a significant .639 in 1999, and the effects of higher education dropped from .948 in 1972 to .511 in 1999 (both highly significant, though). The effects of intergenerational mobility also seemed to have experienced a considerable change, from .321 in 1972 to -.364 in 1999 (both non-significant). Model 3, with the period effects also controlled for, shows that, other things being equal, the overall participation in 1999 was significantly lower than in 1972. Changes in the social structure should have been expected to give rise to increased levels of civic participation, but no such increase is observed. Hall's prediction on the resilience of social capital in Britain is not supported by our data.

When the interaction terms are included in Model 4 of the table, we find, other things being equal, a significant positive change in the effect for the service class, a significant negative change in the effect for intergenerational upward mobility, and yet no significant effects for higher qualifications or for the intermediate class. However, the significant interaction 
effects do not in themselves imply significant changes. For instance, we cannot point to the significant service-class effect in 1999 and say that the service class was significantly more likely to have membership in civic associations in 1999 than they did in 1972. Further analyses in this regard, by combining the main and the interaction effects, show that the serviceclass civic engagement actually fell (though not significantly so), but their decline was simply much less than that among the working class. Similar analyses show that the changes in the effects of intergenerational upward mobility were highly significant. ${ }^{11}$ The last feature may imply a diminishing return to intergenerational upward mobility. It is conceivable that men with intergenerationally upward mobility experience were more likely to engage in civic life as a means of achieving social integration into the destination class at a time when such mobility was of a limited extent than when such mobility was perceived to be much more prevalent, such as at the end of the twentieth century.

In sum, our analysis of associational membership for men between 1972 and 1999 shows neither the across-the-board decline as Putnam would suggest, nor the rising middle-class participation contrasted with the consistently low levels of working-class participation as Hall would expect. Instead, our data show a 'constant fluidity' for the service class and a sharp decline for the working class, together with a reduction in mobility effects. It is also to be noted in this regard that the same substantive conclusion can be reached if we use the number of civic organizations to be the outcome variable as Hall would have done (see data in Appendix Table II). ${ }^{12}$

To gain further insights into the dynamics of socio-cultural attributes and different channels of social capital generation, we conducted multinomial logit models as shown in Table VII, again with 'Neither' as the omitted category and with four models of the same structure as in Model $6 .^{13}$ The data in Table VII show that, in 1972 (Model 1), men with highest educational qualifications and with service-class friends were highly likely to be in the 'Both' and 'Civic' types, men in service-class positions were unlikely to be in 'Both' and 'Labour' types but were highly likely to be 'Civic' type, and men who had experienced intergenerational upward mobility showed considerable origin effects by being significantly more likely to join organizations associated with trade unions and working-men's clubs ('Both' and 'Labour'). Comparing the coefficients in Model 2 with those in Model 1, we see some notable changes. The service-class effect seems to have gone up, from a significant -.742 in 1972 to a non-significant .420 in 1999 for 'Both', from .953 in 1972 to 1.515 in 1999 (both highly significant) for 'Civic', and from -1.622 in 1972 to -1.201 in 1999 (again both significant) for 'Labour'. The effects of higher qualifications, intergenerational upward mobility and having service-class friends seem to have declined in general. The period effects in Model 3 confirm the decline in each of the three membership types versus 'Neither'.

A more crucial test on the trends of socio-cultural factors associated with the different membership types is conducted in Model 4. Here we find that, 
relative to the reference group, the interaction effects between the service class and the period are significant in 'Both' and 'Civic', and those between intergenerational upward mobility and period and between having serviceclass friends and period are significant in 'Civic'. Yet, a formal test of the absolute effects shows no significant changes in the service class between 1972 and 1999 in the two types, confirming that the relative effects described above are due to the sharp decline in the participation among the working class. ${ }^{14}$

\section{DISCUSSION}

In this paper we have explored the patterns and trends of associational membership in England and Wales (1972-1999). We showed that labour and civic associations could be differentiated according to their class composition and the identities of their members. We also tested the thesis of across-the-board decline in social capital put forward by Putnam (2000) and the thesis of rising levels of middle-class social capital proclaimed by Hall (1999). Our results do show some general decline in civic engagement compared to what one might have expected from changes in the social structure, which is in support of Putnam. More important are, however, our findings on the socio-cultural and gender differences in associational memberships. Class differences are most pronounced whereas differences associated with educational qualifications, mobility trajectories and social networks, while still important, are declining. For both men and women, people in higher socio-cultural positions are more likely to take part in civic associations, especially in the 'Civic' and 'Both' types that are generally the preserves of the advantaged. It is also the case that men are more likely to participate in formal civic associations than women in the same class position and with the same level of educational qualifications. It is those in working-class positions, poorly-educated and without service-class friends who are most likely to be disengaged from, hence deprived of access to, any formal channels of social capital. This is particularly true of women in these positions.

Our analysis of the long-term trend does not show a growing access to social capital by the service class although it does show falling levels of social capital by the working class. The service-class participation remained relatively unchanged in terms both of membership per se or of different types of membership. This suggests that a thesis of 'constant fluidity' is a more accurate picture of the service-class civic engagement in British society over the three decades.

We see these changes partly as linked to well-known structural transformation of the UK with an increase in the size of the service class, but would also place our arguments in a broader socio-historical context. In the 1970s it seems possible to distinguish two types of social capital, each relatively strong in different classes. Trade union membership and membership of working men's clubs was associated with the working class, whilst other 
kinds of civic engagement were more common amongst the middle class. We have found that in relative terms middle-class engagement has been subject to 'trendless fluctuation' but working-class engagement has declined beyond that which could be expected purely on the basis of the changing size of the class. This can be related to the arguments of Savage (2000) regarding the collapse of distinct working-class identities in the postwar period. The result is that, even though our results do not fully support some of the specific claims by Hall (1999), we do find his statement that Britain is 'divided between a well-connected and highly-active group of citizens with generally prosperous lives and another set of citizens whose associational life and involvement in politics are very limited' (Hall 1999: 455) as indeed true, and increasingly so.

(Date accepted: August 2003)

Yaojun $\mathrm{Li}$

The Cathie Marsh Centre for Census and Survey Research,

Manchester University

(From September 2003: Department of Sociology,

Birmingham University)

Mike Savage

Department of Sociology,

Manchester University

and

Andrew Pickles

School of Epidemiology and Health Science, and The Cathie Marsh Centre for Census and Survey Research,

University of Manchester 
AT I: Logistic regression models on self-reported working class for men and women (1992-99)

\begin{tabular}{|c|c|c|c|}
\hline & Model 1 & Model 2 & Model 3 \\
\hline \multicolumn{4}{|l|}{ Types of membership } \\
\hline Both & $-.289^{* * *}$ & .023 & $.214^{*}$ \\
\hline Civic & $-.622^{* * *}$ & $-.356^{* * *}$ & -.119 \\
\hline Labour & $.249^{* * *}$ & $.216^{* *}$ & $.201^{*}$ \\
\hline \multicolumn{4}{|l|}{ Neither (base) } \\
\hline \multicolumn{4}{|l|}{ Gender } \\
\hline Female & -.072 & -.099 & -.072 \\
\hline \multicolumn{4}{|l|}{ Male (base) } \\
\hline \multicolumn{4}{|l|}{ Period } \\
\hline 1999 & .093 & $.189^{* * * *}$ & $.158^{*}$ \\
\hline \multicolumn{4}{|l|}{1992 (base) } \\
\hline \multicolumn{4}{|l|}{ Class } \\
\hline Service class & & $-1.095^{* * *}$ & $-2.438^{* * *}$ \\
\hline Intermediate class & & $-.558^{* * * *}$ & $-.499^{* * *}$ \\
\hline \multicolumn{4}{|l|}{ Working class (base) } \\
\hline \multicolumn{4}{|l|}{ Educational qualifications } \\
\hline Degree/professional qualifications & & $-.463^{* * * *}$ & $-.182^{*}$ \\
\hline A/O Levels & & -.009 & .124 \\
\hline \multicolumn{4}{|l|}{ Vocational/none (base) } \\
\hline \multicolumn{4}{|l|}{ Intergenerational mobility } \\
\hline Upward mobility & & & $1.086^{* * * *}$ \\
\hline Downward mobility & & & $-.633^{* * *}$ \\
\hline \multicolumn{4}{|l|}{ Work-life mobility } \\
\hline Upward mobility & & & $.520^{* * * *}$ \\
\hline Downward mobility & & & $-.505^{* * *}$ \\
\hline \multicolumn{4}{|l|}{ Friendship networks } \\
\hline Having service-class friends & & & $-.243^{* * *}$ \\
\hline \multicolumn{4}{|l|}{ Having no service-class friends (base) } \\
\hline Constant & $.214^{* * *}$ & $.829^{* * * *}$ & $.836^{* * * *}$ \\
\hline $\mathrm{N}$ & 7,910 & 7,747 & 4,842 \\
\hline \multirow{2}{*}{$\begin{aligned} \text { Model comparison } & \chi^{2} \\
& p \text {-value }\end{aligned}$} & - & $419.100^{\mathrm{a}}$ & $170.650^{\mathrm{b}}$ \\
\hline & - & $<.001$ & $<.001$ \\
\hline
\end{tabular}

Notes:

1 Adjusted Wald tests are used to test the additional blocks of model terms.

2 a refers to terms in Model 2 that are additional to those in Model 1. ${ }^{\mathrm{b}}$ refers to terms in Model 3 that are additional to those in Model 2.

3 For asterisks please see Note 1, Table III. 
AT II: Regression models on the number of civic organizations for men (1972-99)

\begin{tabular}{|c|c|c|c|c|}
\hline & Model 1 & Model 2 & Model 3 & Model 4 \\
\hline & 1972 & 1999 & 1972-99 & 1972-99 \\
\hline \multicolumn{5}{|l|}{ Main effects } \\
\hline \multicolumn{5}{|l|}{ Class } \\
\hline Service class & -.176 & $.736^{* * * *}$ & .115 & -.107 \\
\hline $\begin{array}{l}\text { Intermediate class } \\
\text { Working class (base) }\end{array}$ & $-.163^{* *}$ & -.127 & $-.160^{* * *}$ & $-.162^{* * *}$ \\
\hline \multicolumn{5}{|l|}{ Educational qualifications } \\
\hline Degree/professional qualifications & $.656^{* * *}$ & $.371^{* * * *}$ & $.515^{* * *}$ & $.620^{* * * *}$ \\
\hline A/O Levels & .068 & .011 & .029 & .053 \\
\hline \multicolumn{5}{|l|}{ Vocational/none (base) } \\
\hline \multicolumn{5}{|l|}{ Intergenerational mobility } \\
\hline Upward mobility & $.194^{*}$ & -.183 & .056 & $.202^{*}$ \\
\hline Downward mobility & $-.151^{*}$ & .135 & -.093 & -.084 \\
\hline \multicolumn{5}{|l|}{ Work-life mobility } \\
\hline Upward mobility & .023 & -.248 & -.069 & -.063 \\
\hline Downward mobility & .079 & -.207 & -.015 & .003 \\
\hline \multicolumn{5}{|l|}{ Friendship networks } \\
\hline $\begin{array}{l}\text { Having service-class friends } \\
\text { Not having service-class friends (base) }\end{array}$ & $.143^{* * *}$ & .121 & $.146^{* * * *}$ & $.139^{* * * *}$ \\
\hline \multicolumn{5}{|l|}{ Period } \\
\hline 1999 & & & $-.498^{* * *}$ & $-.618^{* * *}$ \\
\hline 1972 (base) & & & & \\
\hline \multicolumn{5}{|l|}{ Interaction effects } \\
\hline Service-class in 1999 & & & & $.691^{*}$ \\
\hline Intermediate-class in 1999 & & & & -.034 \\
\hline $\begin{array}{l}\text { Degree/professional qualifications in } \\
1999\end{array}$ & & & & -.202 \\
\hline $\begin{array}{l}\text { Intergenerational upward mobility in } \\
1999\end{array}$ & & & & $-.401^{*}$ \\
\hline Constant & $1.534^{* * * *}$ & $.932^{* * *}$ & $1.516^{* * *}$ & $1.534^{* * * *}$ \\
\hline $\mathrm{N}$ & 5,024 & 1,189 & 6,213 & 6,123 \\
\hline Model comparison $\mathrm{F}(4,6198)$ & - & - & - & $6.040^{\mathrm{a}}$ \\
\hline $\mathrm{p}$-value & - & - & - & $<.001$ \\
\hline
\end{tabular}

Notes:

1 Adjusted Wald tests are used to test the additional blocks of model terms.

2 a refers to terms in Model 4 that are additional to those in Model 3.

3 For asterisks please see Note 1, Table III.

\section{ACKNOWLEDGMENTS}

We wish to thank the Editors and the three referees for their very helpful comments on an earlier version of the paper. We are also grateful to the ESRC for funding the research project 'Social capital: developing a measure and assessing its value in social research' (R000223671) out of which this paper is a product, and to the ESRC Data Archive for making the BHPS data available to us. We alone are responsible for any errors and mistakes in the paper. 


\section{NOTES}

1. Putnam (2000) is generally concerned with overall trends of social capital in American society. He occasionally analyses the data in terms of gender, marital status and age groups (see, for instance, Figures 23, 26 and 39), and mentions the patterns between classes (2000: 108), but does not systematically present evidence of social divisions between socio-economic groups in different types or forms of social capital in the patterns and trends.

2. The BHPS data were originally collected by the ESRC Research Centre on Micro-social Change at the University of Essex (now incorporated within the Institute for Social and Economic Research). Neither the original collectors of the data nor the Archive bear any responsibility for the analyses or interpretations presented here.

3. The distributions of service-class friends are similar across friends. In the SMI, $57 \%, 24 \%$ and $11 \%$ of the respondents in the service-, intermediate- and working- classes said that their firstmentioned friend was in the service class; the figures were $58 \%, 24 \%$ and $11 \%$ for the second-mentioned friend, and $58 \%$, $26 \%$ and $15 \%$ for the third-mentioned friend. Given this, we feel well justified in using the class position of the firstmentioned friend in the SMI in conjunction with the class of the 'best' friend in the BHPS.
4. The SMI asks for the number of memberships within a given type of association whereas the BHPS asks only whether the respondent was member of a given type of association. We thus coded one or more memberships in a given type of association as having membership in that type of association in the SMI.

5. The questions read: '(If you had to choose) Which social class would you say you belong to?' (Wave 1, V3 and Wave 10, V8). As an overwhelming majority of the respondents identified themselves either as working ( $44 \%$ in Wave 1 and $49 \%$ in Wave 10$)$ or middle (40\% and $37 \%)$ classes, we have coded categories 1-3 (lower working, working and upper working) as 'working class' and 4-7 (lower middle, middle, upper middle and upper) as 'middle class'. The question wording is found in http://www.iser.essex.ac.uk/bhps/ doc/pdf_versions/questionnaires/bhpsw1q.pdf and http://www.iser.essex.ac.uk/bhps/doc/ pdf_versions/questionnaires/bhpsw10q.pdf.

We analyse the association between Wave 1 class self-identification with Wave 2 civic membership, and between Wave 10 selfidentified social class membership and Wave 9 civic membership. As no data are available on self-identified class in the SMI, we cannot carry out a similar analysis for 1972.

6. The mobility trajectory (taking intergenerational mobility as an example) is defined as follows:

TABLE VIII:

Respondent's class

Service Intermediate Working

\section{Parent's class}

$\begin{array}{llll}\text { Service } & \text { A } & \text { E } & \text { E } \\ \text { Intermediate } & \text { D } & \text { B } & \text { C } \\ \text { Working } & \text { D } & \text { B } & \text { C }\end{array}$

\footnotetext{
A: Intergenerationally stable service class

B: Intergenerationally stable intermediate class

C: Intergenerationally stable working class

D: Intergenerationally upward mobile into the service class

E: Intergenerationally downward mobile from the service class
} 
Given the way the mobility trajectory is defined, respondents coming from intermediate or working-class families and currently found in intermediate positions are coded as the intergenerationally stable intermediate class. Similarly, respondents coming from these families and currently situated in working-class positions are coded as the intergenerationally stable working class. (The same is done for worklife mobility.) This arrangement is theoretically grounded (Goldthorpe 1987) and has empirical precedence (Clifford and Heath 1993; De Graaf, Nieuwbeerta and Heath 1995; Power et al. 2002). It has the added advantages of using fewer degrees of freedom in the modelling and bringing into sharper relief the class and mobility effects. We have also carried out further analyses using parental class, first job class, current class and interactions between them in this and all other modelling tables. The patterns are the same.

Strictly speaking, we ought to refer to the classes in the modelling tables as inter/intra-generationally stable service class, inter-/intra-generationally stable intermediate class, and inter-/intra-generationally stable working class each time we talk about the class effects. For the ease of expression, we simply refer to them as service, intermediate, and working classes in the text. We note here that, when we talk about the service-class effects, we cannot at the same time talk about downward mobility, for the service class thus defined cannot be downwardly mobile, nor can the working class be upwardly mobile. It does, however, make sense to talk about inter-/intra-generationally upward mobility effects for the service class, and inter-/intra-generationally downward mobility effects for the working class. We are grateful to one of the referees for pointing this out to us.

7. For instance, service-class men had a coefficient of $1.096(.659+.437)$, which is .39 higher than that for service-class women $(.659+.437-.983+.593=.706) . \mathrm{A}$ Wald test yields a chi-square of 5.78 with one degree of freedom, which is significant at the 5\% level. Amongst women, comparisons between the service and the working classes, and between the service and the intermediate classes, are both significant at the $0.1 \%$ levels. Men and women with degrees or professional qualifications are significantly (at the $0.1 \%$ levels) more likely than those with only A/ O Levels or vocational/no qualifications to be in civic organizations.

8. Service-class men were significantly more likely than their female counterparts to be in 'Both' and 'Labour' at the 5\% levels, and intermediate- and working-class men were significantly more so than their female counterparts to be in these types at the $0.1 \%$ levels. At each educational level, men were significantly more likely than women to be in 'Both' and 'Labour', but not 'Civic', types at the $0.1 \%$ levels.

9. Whilst highly educated men are not significantly more likely than poorlyeducated men to be in 'Labour' type, highly-educated women were significantly more likely to be in this type of organizations at the $0.1 \%$ level when all other factors in the model are controlled for.

10. The other variables in the main effects were also tested in interaction with the period dummy either separately or in different combinations. None of them turned out to yield a significant improvement in fit over Model 3. Detailed analyses are available from the authors.

11. The service class effect is .915 in $1999(-.237-1.074+.711+1.515)$ and 1.278 in $1972(-.237+1.515)$. The change is not significant. The Wald test yields a chi-square of 1.82 with one degree of freedom, with a $\mathrm{p}$ value of 0.177 . Even though the effect of higher educational qualification dropped by a factor of 1.074 (1.376 in 1999 and 2.450 in 1972), the interaction effect was not significant at the $5 \%$ level, but the change of 1.74 (.09 in 1999 and 1.83 in 1972) in intergenerational upward mobility is significant at the $0.1 \%$ level, with a chi-square of 29.34 at one degree of freedom.

12. The differences between our results and those by Hall (1999) may be due to the data and the methods used. Hall relies on a mixture of cultural and political surveys whereas we use the most authoritative social surveys available in the country. Hall uses a somewhat dated fourway class schema (upper middle, nonmanual/clerical, skilled manual and lower skilled manual) while the class schema we 
use is widely claimed as the best of all existing sociological endeavours in terms of theory, utility and validity (Rose and O'Reilly 1998; Marshall et al. 1988). We also conduct more sophisticated statistical models to discern the patterns and trends whereas Hall's interpretations are generally based on cross-tabulations.

13. We have carried out other tests by including period and intermediate class, and/or period and A/O Levels. Neither the interaction terms nor the global tests turned out to be significant.

14. The service-class effects dropped by .338 (-1.375-1.307) in 'Both' and .095 in 'Civic' (-.847-.754). The Wald tests show that neither is significant, with chisquare values being .870 and .095 at one degree of freedom and $p$ values at .351 and .767 respectively. The drop of 1.634 in intergenerationally upward mobility and 1.256 in having service-class friends were highly significant at the $0.1 \%$ levels, with chi-square values being 22.81 and 29.36 respectively with one degree of freedom.

\section{BIBLIOGRAPHY}

Abbott, A. 2001 The Chaos of Disciplines, Chicago: University of Chicago Press.

Anheier, H. and Kendall, J. 2002 'Interpersonal Trust and Voluntary Associations: Examining Three Approaches', British Journal of Sociology, 53(3): 343-62.

Binder, D. A. 1983 'On the Variances of Asymptotically Normal Estimators From Complex Surveys', International Statistical Review 51: 279-92.

Bourdieu, P. 1984 Distinction: A Social Critique of the Judgment of Taste, London: Routledge and Kegan Paul.

1986 'The forms of capital' in J. Westport (ed.) Handbook of Theory and Research for the Sociology of Education, New York: Greenwood, 214-58.

British Household Panel Survey [computer file] principal investigator, ESRC Research Centre on Micro-social Change, Colchester: The Data Archive [distributor], 2001. Data files and associated documentation.

Clifford, P. and Heath, A. 1993 'The Political Consequences of Social Mobility',
Journal of the Royal Statistical Society, Series A (Statistics in Society), 156(1): 51-61.

Cohen, J. L. and Arato, A. 1992 Civil Society and Political Theory, Cambridge, Mass.: MIT Press.

Coleman, J. S. 1988 'Social Capital in the Creation of Human Capital', American Journal of Sociology 94: S95-S120.

De Graaf, N. D., Nieuwbeerta, P. and Heath, A. 1995 'Class Mobility and Political Preferences: Individual and Contextual Effects', American Journal of Sociology 100(4): 997-1027.

Fine, B. 2001 Social Capital versus Social Theory: Political Economy and Social Science at the Turn of the Millennium, London: Routledge.

Foley, M. W. and Edwards, B. 1997 'Escape From Politics? Social Theory and the Social Capital Debate', American Behavioral Scientist 40(5): 550-61.

Gallie, D., Penn, R. and Rose, M. (eds) 1996 Trade Unionism in Recession, Oxford: Oxford University Press.

Goldthorpe, J. H. with Llewellyn, C. and Payne, C. 1987 Social Mobility and Class Structure in Modern Britain, Oxford: Clarendon Press.

Hall, P. A. 1999 'Social Capital in Britain', British Journal of Political Science 29: 417-61.

Heath, A. F. 1981 Social Mobility, London: Fontana.

Huber, P. J. (1967) 'The Behaviour of Maximum Likelihood Estimates Under Non-Standard Conditions', in Proceedings of the Fifth Berkeley Symposium on Mathematical Statistics and Probability, Berkeley, CA: University of California Press.

Jackman, R. and Miller, R. 1998 'Social Capital and Politics', Annual Review of Political Science 1: 47-73.

Levi, M. 1996 'Social and Unsocial Capital', Politics and Society 24: 44-55

Li, Y. 1997 The Service Class: Theoretical Debate and Sociological Value, D.Phil Thesis, Nuffield College, Oxford University. 2002 'Falling Off the Ladder? Professional and Managerial Career Trajectories and Unemployment Experiences', European Sociological Review 18(3): 253-70.

Li, Y., Savage, M., Tampubolon, G., Warde, A., and Tomlinson, M. 2002 'Dynamics of Social Capital: Trends and Turnover in Associational Membership in 
England and Wales: 1972-1999', Sociological Research Online 7(3).

Li, Y., Savage, M. and Pickles, A. 2003 'Social Change, Friendship and Civic Participation', forthcoming, Sociology Research Online.

Lin, N. 2001 Social Capital, Cambridge: Cambridge University Press

Marshall, G., Rose, D., Newby, H. and Vogler, C. 1988 Social Class in Modern Britain. London: Hutchinson.

Marshall, G., Swift, A. and Roberts, S. 1997 Against the Odds? Social Class and Social Justice in Industrial Societies, Oxford: Clarendon Press.

Mitchell, C. J. and Critchley, F. 1985 'Configurational Similarity in Three Class Contexts in British Society', Sociology 19: 72-92.

Parry, G., Moyser, G. and Day, N. 1992 Political Participation and Democracy in Britain, Cambridge: Cambridge University Press.

Paxton, P. 1999 'Is Social Capital Declining in the United States? A Multiple Indicator Assessment', American Journal of Sociology 105: 88-127.

Portes, A. 1998 'Social Capital: Its Origins and Applications in Modern Sociology', Annual Review of Sociology 24: 1-24.

Power, C., Stansfeld, S. A., Matthews, S., Manor, O. and Hope, S. 2002 'Childhood and Adulthood Risk Factors for Socioeconomic Differentials in Psychological Distress: Evidence from the 1958 British Birth Cohort', Social Science Ẽ Medicine 55: 1989-2004.
Putnam, R. 1993 Making Democracy Work: Civic Traditions in Modern Italy, Princeton, N.J.: Princeton University Press.

— 1995 'Bowling Alone: America's Declining Social Capital', Journal of Democracy $6(1)$ : $65-78$.

1996 'The Strange Disappearance of Civic America', American Prospect 24: 34-48.

2000 Bowling Alone: The Collapse and Revival of American Community, New York: Simon \& Schuster.

Rose, D. and O'Reilly, K. 1998 Final Report of the ESRC Review of Government Social Classifications, Swindon: ESRC/ONS.

Savage, M. 2000 Class Analysis and Social Transformation, Buckingham: Open University Press.

Scott, J. 1991 Who Rules Britain? Cambridge: Polity.

Skocpol, T. 1996 'Unravelling from Above?', The American Prospect 25. http:// www.prospect.org/archives/25/25cmt2.html

Urry, J. 1981 The Anatomy of Capitalist Societies, London: Hutchinson.

2002 'Mobility and Proximity', Sociology 36(2): 255-74.

Walters, W. 2002 'Social Capital and Political Sociology: Re-imagining Politics?', Sociology 36(2): 377-97.

Warde, A., Tampubolon, G., Tomlinson, M., Ray, K., Longhurst, B. and Savage, $M$. 2001 'Tendencies of Social Capital: Dynamics of Associational Membership', Paper delivered to the BSA Annual Conference, Manchester, April.

White, H. (1982) 'Maximum Likelihood Estimation of Misspecified Models', Econometrica 53: 1-16. 